\title{
El estoicismo a la luz de la noción de tiempo: Lógica, Física y Ética
}

\author{
Stoicism in the light of Time: \\ Logics, Physics, Ethics
}

\author{
Antonio Dopazo Gallego \\ (Universidad Complutense de Madrid)
}

Recibido: 03/09/2012

Aceptado: 19/03/2013

\section{Resumen}

El presente artículo se propone aclarar la doble lectura del tiempo presente en los documentos conservados de la escuela estoica, sirviéndose para ello del paralelismo existente entre el tiempo y los demás incorpóreos -la pareja vacío-lugar y el expresable- y ampliando la investigación a la Ética, disciplina que sirve de coronamiento al sistema y desde la que es posible apreciar con mayor nitidez el papel clave que la noción de tiempo desempeña en el conjunto del estoicismo y en su hostil reacción frente al aristotelismo.

Palabras clave: Tiempo, movimiento, Estoicos, Crisipo, Marco Aurelio, Zenón, materia, Aristóteles, pneûma, instante, duración.

\section{Abstract}

This paper tries to clarify the double reading of time found in the surviving sources of the Stoic School, making use of the parallelism between time and the other incorporeals (the couple void-place and the so-called sayable). Secondly, it aims to extend the research to Ethics, a discipline that acts as the summit to the system and from which it is possible to grasp the key role that Time plays in Stoicism as a whole and in its bitter reaction against Aristotelism.

Keywords: Time, motion, Stoics, Chrysippus, Marcus Aurelius, Zeno, matter, Aristotle, pneûma, instant, duration. 


\section{El problema del tiempo en el estoicismo. Instante y duración}

I. La reconstrucción conceptual de doctrinas que nos han sido legadas en estado de ruina documental es uno de los escollos habituales a los que se enfrenta el historiador de la filosofía antigua. Un ejemplar único, por espinoso, de esta clase de desafíos constructivos es el que ofrece la doctrina estoica del tiempo. Si bien la problemática gozó de cierta difusión a finales de los años sesenta con la publicación de Lógica del sentido, donde el filósofo Gilles Deleuze ofrecía una original solución a la misma amparándose en la ingente labor de los historiadores Émile Bréhier y Victor Goldschmidt, lo cierto es que la cuestión dista de haber quedado zanjada, e incluso muchos de los actuales estudios consagrados al tema continúan admitiendo su incapacidad a la hora de esclarecer lo que para algunos de ellos constituye un galimatías filosófico y un «campo de minas documental», bien renunciando a armonizar la doctrina, bien ofreciendo de ella una lectura claramente mutilada1.

II. El gran problema reside en conciliar lo que parecen ser dos lecturas del tiempo, una lógica y otra física (recuérdese la categorización estoica de la filosofía, por orden de exposición, en Lógica, Física y Ética²). En los textos de la Antigua Estoa transmitidos por Diógenes Laercio, Estobeo y Plutarco, y especialmente en aquellos que reflejan las opiniones de Crisipo -el más avezado de sus miembros en materia lógica ${ }^{3}$ - se observa una concepción abstracta del tiempo que sugiere una marcada influencia aristotélica. El tiempo, leemos repetidamente en estos textos, es «ilimitado (ápeiron) por ambos lados -pasado y futuro- $\rangle^{4}$ e «infinitamente divisible [eis ápeiron tomé, como corresponde a los continuos], de modo que ningún tiempo es presente en sentido estricto» 5 . Plutarco añade, en esta línea, que los estoicos «no admiten una unidad mínima de tiempo» 6 (eláchiston chrónon), o lo que es lo mismo, «no pretenden que el instante actual sea indivisible [o 'carezca de partes']»7 (frente a los epicúreos, se entiende, que sí manejaban un ahora mínimo, indivisible, sin partes pero parte él mismo del tiempo), «[y alegan que] de cualquier momento

\footnotetext{
1 Para un resumen de las principales tendencias historiográficas al respecto (Kidd, Sorabji, Long/Sedley, Hadot y la Historia de la Filosofía de Cambridge), cf. Sellars, J., "Aiôn and Chronos: Deleuze and the Stoic Theory of Time», en Collapse, Philosophical Research and Development, Vol. III, 2007. Sellars, por su parte, procede a un estudio de la cuestión a nuestro entender parcial e insatisfactorio, y su artículo parece escrito en la tradición polémica de un Plutarco.

2 Diógenes Laercio, Vidas de los filósofos ilustres, Madrid, Alianza, 2008 (desde ahora DL), VII, 40.

3 Cf. DL VII, 180.

4 Ario Dídimo, en Estobeo, I 8, 42 (Ario Dídimo, fr. 26, recogido también como fr. 412 en Crisipo de Solos, Testimonios y fragmentos, Vol. II, Madrid, Gredos, 2006), así como DL VII, 141.

5 Ibid.

6 Plutarco, Sobre las nociones comunes, contra los estoicos, 1081c-1082a, en Obras morales y de costumbres XI, Madrid, Gredos, 2004 (trad. cast. Raúl Caballero Sánchez).

7 Ibid.
} 
que uno cree [cursiva nuestra] concebir y captar como presente (enestós), una parte pertenece al futuro y otra al pasado» 8 . Incidiendo en esta definición y citando al estoico Arquédemo (quien vivió presumiblemente en el siglo III a.C., hacia el fin de la Antigua Estoa), Plutarco añade que «el 'ahora' (nyn) es una suerte de juntura y conexión entre el pasado y el futuro [...]; el 'ahora' no es tiempo (chrónos), sino un límite (péras) del tiempo» ${ }^{9}$. Posidonio remata la comparación con Aristóteles en un fragmento citado por Ario Dídimo: «el presente está formado por una parte (méros) del pasado y una parte del futuro, comprendiendo la división misma [o 'el límite divisor', según traduce Kidd]; y la división (diorismón) es puntual [semeiode, es decir, como el punto respecto a la línea: inextenso y no siendo parte de ella, pues la línea no es suma de puntos]» ${ }^{10}$. Por tanto, el «ahora» propiamente estoico no es una porción mínima de tiempo, sino un mero límite abstracto («no es parte del tiempo», diría Aristóteles), pura división entre el pasado y el futuro.

Al mismo tiempo, en el mismo conjunto de doxografías y frente a esta concepción evasiva y fugaz del «ahora», se nos ofrece una cita enormemente enigmática, aparentemente contradictoria con las anteriores pero ciertamente auténtica (pues nos llega a través de dos fuentes distintas, de nuevo Plutarco y Ario Dídimo): «[para Crisipo] sólo el presente existe (hypárchein ${ }^{11}$ ); el pasado y el futuro subsisten (hyphestánai), pero no existen en modo alguno, como se dice también que existen en calidad de predicados sólo los atributos actuales; por ejemplo, el pasear se da en mí [o 'me pertenece'] cuando paseo, pero no cuando estoy recostado o sentado»12, o bien: «Crisipo, en su afán de rizar el rizo con la división del tiempo, afirma en Sobre el vacio y otras obras que la parte del tiempo (chrónos) que pertenece al pasado y al futuro no existe (hypárchein), sino que subsiste (hyphestekénai) y que sólo el presente tiene existencia real (hypárchein)» ${ }^{13}$.

El conjunto de las fuentes nos pinta así un cuadro problemático que deja traslucir dos nociones opuestas del tiempo: el «ahora» o instante ${ }^{14}$ y el «presente». El primero ha sido caracterizado previamente como inextenso y abstracto (ilusorio por cuanto «no es un tiempo», sino un límite divisor del tiempo infinito), mientras que, por su parte, el presente existe y parece poseer cierta duración limitada (la de la

\footnotetext{
8 Ibid.

9 Ibid.

10 En Posidonius, Vol. 1, The fragments, L. Edelstein e I.G. Kidd (eds.), Cambridge University Press, 1989, y Posidonius, Vol. 3, The translation of the fragments, I.G. Kidd, Cambridge University Press, 1999.

11 Sobre este término griego tardío, hypárchei, véase Agustín García Calvo, De Dios, Zamora, Lucina, 1996, p. 28.

12 Ario Dídimo, loc. cit.

13 Plutarco, loc. cit.

14 No, desde luego, «instante actual», pues la existencia de tal noción es la que se ha venido negando más arriba, sino más propiamente «inactual».
} 
acción expresada por el predicado actual que se le atribuye al agente), lo que le otorga una clara preeminencia ontológica que contrasta con el humilde estatuto abstracto y lógico del instante. Desde esta posición de máxima problematicidad, explotada por el platónico Plutarco para denunciar el absurdo de la doctrina estoica, nos proponemos resolver el aparente enigma apelando a las indicaciones que arrojan las propias fuentes documentales y que a nuestro entender permiten resolverlo a condición de tomarse cierta molestia en integrar la doctrina del tiempo en la totalidad del sistema estoico y no valerse de ella al modo de una suerte de extravagante porción desgajada del conjunto. A lo largo del siguiente texto, por consiguiente, nos veremos obligados a transitar por las tres partes del sistema: tanto por la marcada oposición inicial entre Lógica y Física como por la eventual y original solución a la doctrina del tiempo encarnada en la figura del sabio estoico, terreno de la Ética. Entre tanto, no nos quedará más remedio que cambiar eventualmente de fuentes documentales, pues los textos en los que más diáfana aparece la cuestión ética no pertenecen ya a la Antigua Estoa (pese a haber en ella inequívocas muestras que apuntan en la misma dirección), sino al Estoicismo Nuevo de Séneca, Epicteto y Marco Aurelio. La sistematicidad de la doctrina, en cualquier caso, es mantenida perfectamente a cubierto, o eso trataremos de mostrar.

III. Según sabemos por Sexto Empírico, los estoicos incluyen el tiempo (chrónos) en la lista de lo que ellos llaman «los incorpóreos» junto al expresable (lektón), el vacío (kenón) y el lugar (tópos) ${ }^{15}$. El estatuto ontológico de este cuarteto, como la propia palabra empleada para designarlos, es una innovación conceptual específicamente estoica: se diferencian del ser (ón) y sólo quedan recogidos junto a él bajo la categoría más general de «algo» ( $t i$ ), que engloba a los cuerpos (que son lo propiamente existente y materia de la Física) y estos cuasi-seres (o abiertamente noseres, tan frágil es su estatuto) que son los incorpóreos ${ }^{16}$, materia de la Lógica y la dialéctica. Todos los incorpóreos pueden reducirse a una noción única, la de «atributo» (kategórema) de los cuerpos, aunque es preciso entender este atributo no en el sentido de una cualidad física como el color o la dureza, que son «propiedades» activas y corpóreas, sino en el de un efecto o índice de dichas actividades que ilustra su «modo de ser» (pos échon ${ }^{17}$ ) y no modifica realmente al sujeto en cuestión ${ }^{18}$.

\footnotetext{
15 Sexto Empírico, Adv. Math., X, 218 (Contra los profesores, Madrid, Gredos, 1997).

16 Cf. Alejandro de Afrodisia, en Tópicos, IV, 155 y 180, y la reacción de Plotino en Enéadas, VI 1, $25,6-10$. Para una discusión ampliada de esta noción vacía de $t i$, que en ocasiones parece una burla expresa del aristotelismo, cf. Goldschmidt, V., Le système stö̈cien et l'idée de temps, París, Vrin, 1969, $\S 1-6$, de donde tomo ambas citas.

17 Cf. Bréhier, La théorie des incorporels dans l'ancien stö̈cisme, París, Vrin, 1987 (7ª ed.), pp. 12, 42-43.

18 En cuanto al vacío, parece ser el único incorpóreo del cual no sería correcta la definición de «atributo de un cuerpo» (a menos que se aceptara que de los cuerpos puede predicarse algo meramente posible), que habría de ser sutilmente modificada por la de «atributo del Todo». Cf. Sexto, Adv. Math., IX, 332 y Bréhier, op. cit., p. 49.
} 
Sea cual sea el nivel de incomprensión que esto genere en un lector moderno, quizá sea posible atenuar la perplejidad y entender el alcance de esta brecha ontológica si pensamos en el profundo rechazo a las concepciones pitagóricas, platónicas y aristotélicas del límite que late bajo el edificio conceptual del estoicismo.

Como dice Émile Bréhier al comienzo de su estudio clásico, «un rasgo característico de las filosofías nacidas tras Aristóteles es su rechazo de toda causa inteligible e incorpórea como explicación de los seres reales» ${ }^{19}$. Lo que esto implica por lo pronto en el caso de los estoicos es una desconexión entre Lógica y Física que supone deshacer por completo la descomunal empresa filosófica llevada a cabo por Aristóteles. El neoplatónico Proclo, en su comentario a los Elementos de Euclides, nos ha conservado un testimonio que expresa a las claras el modo en que los estoicos resumieron el platonismo: las Ideas, según Crisipo, «comprenden la génesis de seres indefinidos en límites determinados ${ }^{20}$. La única preocupación del platonismo -y aquí se incluye a Aristóteles- a ojos de Crisipo es ese límite determinante que, una vez definido, sería capaz de engendrar por sí solo un sinnúmero de seres; el ser corpóreo como tal es lo de menos porque es pensado como el fondo indiferente que queda circunscrito en un contorno formal geométrico al modo del bloque de piedra modelado por el escultor. El tema dominante de esta ontología es así la relación entre el límite y lo ilimitado, ya sea al modo de la participación o de la inherencia: a ojos del estoico dicha relación no es más que un burdo molde ideal que se le aplica a una materia pudorosamente instalada en el fondo mismo de la realidad sensible como principio de cambio, corrupción y muerte ${ }^{21}$. Cuando los estoicos privan de toda realidad y capacidad de influencia a los incorpóreos, su intención no es otra que la de sabotear esta relación de determinación: ya no es la materia indefinida la que se individúa y define al recibir un límite ideal, sino que el cuerpo se presenta siempre ya individuado y cualificado en virtud de la porción de pneûma (hálito vital) que lo cohesiona desde dentro 22 . Al mismo tiempo, los objetos del pensamiento lógico no son ahora más que efectos o índices que acompañan al acto real

\footnotetext{
${ }^{19}$ Ibid., p. 1.

20 Proclo, In Euclides, 35, 25 (citado por Bréhier, op. cit., p. 3).

21 Siempre, eso sí, al modo de la potencia salvaje embridada por la forma encargada de otorgarle un contorno estable y hacerla pasar al acto. Recuérdese la insistente argumentación contra la existencia de un espacio vacío independiente en el libro IV de la Física (215 a-b), donde se alega que en él no se podría descubrir ninguna determinación positiva: ni alto, ni bajo, ni la velocidad de un móvil que lo recorre, que sería infinita e indefinida.

${ }^{22}$ Lo particular del pneûma cohesivo, además de su inmanencia, es su corporeidad, según la máxima estoica de que todo lo real es corpóreo. En este sentido, y según Crisipo, el pneûma es una mezcla sutil de aire y fuego, elementos ellos mismos corpóreos (pero simples) formados por la primera distensión del fuego primordial o inteligencia divina. A partir del pneûma se constituyen los otros dos elementos, agua y tierra, además de los cuerpos compuestos. Cf. nota 358 a Plutarco, Contradicciones de los estoicos, y nota 415 a Nociones Comunes (Raúl Caballero, ed. Gredos).
} 
de un cuerpo, sin que haya entre los dos ámbitos ontológicos ninguna posible relación de causalidad fuerte (que se ha vuelto patrimonio exclusivo de los cuerpos, siendo los que actúan y padecen).

IV. La puesta en juego de esta desconexión entre Física y Lógica queda bien ilustrada en la pareja de incorpóreos mejor documentada: el vacío y el lugar, a partir de los que se hace posible entender los otros dos. Para concebir el vacío, los estoicos proceden a retirar todas las determinaciones del cuerpo: el vacío infinito, situado en el exterior de un universo continuo, lleno y limitado, es definido como «la ausencia de cuerpo»o «el intervalo privado de cuerpo» 23 , mientras que el lugar, en claro contraste, es definido como «lo que está enteramente ocupado por un cuerpo» ${ }^{24}$. Al contrario de lo que ocurría en Aristóteles, sin embargo, y en virtud de su condición de incorpóreo, el lugar no puede envolver al cuerpo contenido en un sentido físico (es decir, no hay contacto entre una cosa y su lugar actual, como se exigía en la Física ${ }^{25}$ ), sino que se limita a aportarle un continente abstracto que constituye un resultado de la acción del propio cuerpo (dicho de otro modo: el vacío se vuelve lugar al quedar vinculado a un determinado cuerpo del mundo, pero sin que esta vinculación implique en ningún caso la corporeidad del propio lugar). Para que esta noción meramente «lógica» del lugar como intervalo lleno cobre sentido y escape a las aporías que Aristóteles le había señalado en la Física (como que varias cosas podrían ocupar un lugar a la vez y en el mismo sentido) es necesario, en cualquier caso, considerar la profunda revisión de las nociones de cuerpo y movimiento llevada a cabo por los estoicos, cuyas características nos son bien conocidas.

La principal innovación del estoicismo en materia física consiste en ubicar exclusivamente en el mundo los cuerpos penetrados de hálito vital y reducidos a puro acto. Podemos casi palpar en los textos conservados la repugnancia que un estoico siente por la concepción de lo corpóreo como parcialmente indefinido y del movimiento como restitución de una carencia. El movimiento, dirán ellos contra

\footnotetext{
23 Aecio, Plac. I, 20, 1 (SVF II, 163, 7); Sexto Empírico, Adv. Math., X, 3 (11, 19). También es llamado por Cleómedes «el pensamiento más simple». Cf. Bréhier, op. cit., p. 47.

24 «O es susceptible de serlo» (Estobeo, Eclogae, I, 161, 8 [SVF II, 162, 39]), citado por Bréhier, op. cit.

25 Cuando Aristóteles define el lugar de una cosa como «el primer límite inmóvil de lo que la contiene» (Phys. IV, 212 a 20), parece estar operando una ósmosis entre lo lógico (el límite inmóvil, que por su carácter ideal no podría estar meramente «en reposo» y sirve de contorno o parada abstracta al móvil) y lo físico (la división actual -ruptura de la continuidad- que opera el lugar en el movimiento rectilíneo cuando se le atribuye a un cuerpo). Como el «ahora» (ver más abajo la nota 40), el lugar divide el continuo y religa los cortes, y entre ambos configuran un verdadero aqui-y-ahora del móvil tratado que lo vuelve accesible a la simultaneidad del acto de habla. Para un desarrollo del carácter a la vez ideal y físico del lugar, cf. Goldschmidt, V., La théorie aristotélicienne du lieu, 18-19, en Écrits I, París, Vrin, 1984; para los paralelismos entre el lugar y el instante aristotélicos, así como entre el móvil, la entidad y el sujeto, véase Categorías, VI.
} 
Aristóteles, no es el paso de la potencia al acto ${ }^{26}$, sino un acto siempre acabado 27 , resultado de la tensión pneumática que se difunde ondulatoriamente a través del cuerpo y que, además de extenderlo en el espacio, lo cohesiona por un lazo interno, héxis (disposición o inter-posesión) tendida de un extremo al otro del individuo que le permite seguir siendo el mismo a través de cada uno de sus cambios ${ }^{28}$. La noción de una forma determinante, por orgánica que ésta sea -especie-, es también reemplazada por el pneûma o hálito vital, cuerpo sutil que recorre y penetra a todos los individuos formando entre ellos, a gran escala, un destino corpóreo o unidad de todas las causas 29 identificado finalmente con el propio mundo (noción estoica de Zeus-Día como divinidad corpórea respecto a la cual todas las sustancias individuales constituyen no divisiones, sino distensiones parciales ${ }^{30}$ ).

Las consecuencias para la noción de límite son muy profundas: el contorno estoico ya no es concebido a imagen del modelado del escultor sobre el bloque de piedra (que exigía una forma preexistente y de naturaleza ajena a la propia materia), sino al modo del área de influencia o radio de acción de un ser vivo. El límite es dado ahora por el estado de tensión (tónos) o la potencia que se ejerce, al modo, como dice Émile Bréhier ${ }^{31}$, del germen de la planta, que siempre está «en acto», incluso allí donde no ha alcanzado el culmen de su desarrollo. Esta ontología tonal (versus formal), además de impugnar la noción de especie aristotélica (pues las sustancias corpóreas aparecen ahora cualificadas de suyo por algo que es a su vez corpóreo), posee unas implicaciones cruciales para la concepción del lugar, hasta el punto de que no se entendería su ubicación entre los incorpóreos (y, por tanto, su radical incapacidad para determinar a los agentes) si no se percibe que los propios cuerpos, en sus acciones, operan un verdadero proceso de espacialización respecto al cual el lugar como intervalo sólo constituye el necesario «efecto», «acompañamiento» o «síntoma» derivado: la medida abstracta resultante de la acción de un cuerpo (y no de su relación de posición con algún otro) ${ }^{32}$.

\footnotetext{
26 Para ser totalmente justos con Aristóteles, el movimiento no aparece nunca definido así en su obra. Si empleamos la fórmula «escolastizada» es para resaltar el peso de lo potencial, tan ajeno al estoicismo, en la definición. Tampoco nos parece casual que los estoicos leyeran a Aristóteles en clave similar a como lo hicieron los autores medievales. A este respecto, cf. Pardo, José Luis, El cuerpo sin órganos, Valencia, Pre-textos, 2011, «Excursus I: El movimiento antiguo».

$27 \mathrm{O}$ «un acto que se repite siempre de nuevo», según atribuye Eusebio a Crisipo (Praeparatio Evangelica, 18, 3).

28 Uso aquí héxis en un sentido amplio concerniente a todos los cuerpos, no restringido a la naturaleza inorgánica. Cf. nota 417 a Plutarco, Nociones comunes, y 358 a Contradicciones de los estoicos (Raúl Caballero, ed. Gredos).

29 DL VII, 149: «El destino es la causa encadenada de los entes, o bien la razón según la cual se conduce el universo» (trad. cast. Carlos García Gual).

30 Cf., por ejemplo, DL VII, 147. El pneûma constituye a su vez una distensión del lógos, razón ordenadora y seminal -también corpórea- que es a la que se llama propiamente alma de Dios (ver nota 22).

31 Op. cit., p. 12.

32 Cf. Bréhier, op. cit., pp. 42 y 47.
} 
V. Gracias a dos textos cruciales de la Antigua Estoa podemos apreciar el riguroso paralelismo que se da entre las nociones de vacío y lugar y las dos acepciones correspondientes del tiempo (chrónos). En el primero de ellos, Ario Dídimo atribuye a Crisipo la opinión de que «del mismo modo [cursiva nuestra] que el vacío es en su totalidad ilimitado (ápeiron) por doquier, también el tiempo (chrónos) es todo él (pánta) ilimitado en los dos sentidos (eph'ekátera), pues tanto el pasado como el futuro son ilimitados» ${ }^{33}$. En segundo lugar, Diógenes Laercio nos ha conservado en su exposición de Zenón de Citio la que puede considerarse como definición canónica del tiempo estoico, y en la que se aprecia una clara voluntad de armonizarlo con el lugar: «También el tiempo (chrónos) es incorpóreo (asómatos), siendo el intervalo (diástema) del movimiento (kínesis) del universo. Del tiempo, el pasado y el futuro son infinitos (ápeiron), pero el presente es limitado» 34 .

Estas dos definiciones, la segunda de las cuales está curiosamente ausente de la exposición aporética de Plutarco, permiten empezar a disolver la aparente paradoja de los planteamientos iniciales de este artículo distinguiendo un tiempo «total»o «ilimitado» en pasado y futuro de un tiempo interválico, determinado por el movimiento -es decir, por el acto- de un cuerpo, que adopta el aspecto de un «presente limitado» 35 . La correspondencia tiempo-espacio es meridiana en este punto: del mismo modo que el lugar como síntoma era dado por la razón interna que extendía el cuerpo en el espacio, lo que llamamos tiempo presente es resultado de un acto de temporalización paralelo que determina los límites del movimiento (dicho de otro modo: en el «tiempo presente», lo presente no es realmente el tiempo, sino el acto del cuerpo). Y si el lugar definido por el cuerpo total era el del propio universo en mitad del vacío, el tiempo definido por el movimiento total será el presente simultáneo de un ciclo cósmico en mitad de la infinitud pasada y futura del tiempo ${ }^{36}$.

33 Ario Dídimo, fr. 26 (Estobeo). Ver nota 4.

34 DL VII, 141. Esta definición es repetida además en dos ocasiones por Ario Dídimo (fr. 26, Estobeo, I 8,42), quien la atribuye a Crisipo y Posidonio. Nótese la sutil diferencia con la definición aristotélica del tiempo como «número del movimiento (arithmós kinéseos) según el antes y el después»: el «número» se ha tornado «intervalo», lo cual parece directamente relacionado con la parte final de la fórmula, que afirma que, frente al pasado y el futuro, el presente es «limitado».

35 Fue Crisipo, según Simplicio, quien introdujo la exigencia de definir el tiempo en función del movimiento más dilatado de todos: el del universo corpóreo en su totalidad, respecto al cual los otros serían distensiones parciales (Crisipo de Solos, op. cit., fr. 413).

36 Los estoicos mantuvieron la creencia generalizada en ciclos cósmicos repetitivos de extensión-distensión escandidos por conflagraciones (ekpúrosis) que tenían lugar en el momento de máxima dilatación del mundo y en las que éste alcanzaba su máxima pureza ígnea, deviniendo propiamente Zeus (razón divina o principio activo). Tras cada conflagración se iniciaba el proceso inverso de distensión (diakósmesis), durante el cual el vacío le «ganaba terreno» al mundo a medida que éste se conformaba y el Alma cósmica perdía paulatinamente su tensión y, por ende, su volumen corpóreo (en los estoicos, frente a la moderna termodinámica, el mundo se expande porque se vivifica: el lugar crece o mengua como acontecimiento o índice incorpóreo de mayor o menor tensión del principio divino, respec- 
Para terminar de resolver el enigma de la multivocidad del tiempo nos quedaría entender qué papel desempeña exactamente en la doctrina el «ahora» o instante inactual-inextenso de aparente influencia aristotélica al que aludían los textos citados al comienzo, así como aclarar el significado preciso de la «existencia» del presente frente a la «subsistencia» de pasado y futuro de la que hablaba Crisipo relacionándola con los predicados expresables del tipo «paseo», «estoy tumbado»o «estoy sentado». Esto último permitirá extender el paralelismo al tercer grupo de incorpóreos, los expresables.

VI. Crisipo desarrolló un método de división de los continuos destinado, entre otras cosas, a demostrar la rigurosa irrealidad del tiempo y su desconexión causal, como ente lógico, de todo ente corpóreo. Ario Dídimo lo transmite así: «[Crisipo] dice con toda claridad que ningún tiempo (chrónos) es absolutamente [o 'rigurosamente'] presente (hólos enistatai). Dado que la división (tomé) de los continuos es ilimitada, conforme a esta división también el tiempo (chrónos) todo se divide ilimitadamente (eis ápeiron tomé), de modo que ningún tiempo es presente en sentido estricto (kat' apartismòn enestánai), sino que esto se dice en sentido lato [o 'según una cierta extensión', katà plátos]»37. Plutarco añade una frase significativa: «de cualquier momento que uno cree captar con el pensamiento como presente, una parte pertenece al pasado y otra al futuro» ${ }^{38}$.

Lo que Crisipo pone en juego con la división infinita en pasado y futuro a través de este instante inaprehensible es el sabotaje absoluto de una noción de tiempo que conservara algún tipo de estabilidad al margen de los cuerpos. En tanto ente noético dominio de la Lógica, el tiempo no posee determinaciones intrínsecas; no hay en él cortes naturales o segmentos inmanentes, de modo que ningún presente pertenece de suyo al tiempo (al igual que el vacío carecía de lugares naturales o divisiones propias), sino a los cuerpos, que son los que determinan su propia medida. Pero en segundo lugar y de forma más significativa, la dislocación entre Lógica y Física se confirma marcando una distancia con respecto a Aristóteles. Éste ya no admitía que el «ahora» fuera tiempo (no era parte del tiempo como el punto no era

tivamente; a mayor distensión, mayor contracción neumática y mayor vaciamiento). En este sentido podían decir que Dios es infinito pero definido (frente al vacío, infinito e indefinido). Cf. por ejemplo Marco Aurelio, Meditaciones, Madrid, Cátedra, 2011, 12.32, así como Raúl Caballero, «Plutarco y el modelo cosmológico-espacial de Crisipo: ¿el mundo en el centro del vacío?», en: A. Casanova (ed.), Plutarco e l'etá ellenistica, Florencia, Università degli studi di Firenze, 2005.

37 Estobeo, loc. cit. (trad. cast. F. Javier Campos Daroca y Mariano Nava Contreras, en Crisipo de Solos, op. cit., fr. 412). Respecto a la traducción de katá plátos, los comentaristas modernos no se ponen de acuerdo. La versión entre paréntesis pertenece, entre otros, a Victor Goldschmidt (Le système stoïcien et l'idée de temps, p. 31). Cualquiera de las dos, a nuestro parecer, es válida para entender el fragmento.

38 Plutarco, loc. cit. Empleamos en este caso la traducción de Bréhier. Raúl Caballero traduce en Gredos «que uno cree concebir y captar como presente». En ambos casos se apela a un tiempo pensado o noético como opuesto al que corresponde a una percepción sensible. 
extensión o parte de la línea), pero comoquiera que él siempre consideraba el tiempo en límites determinados por el comienzo y el fin de un movimiento, el «ahora» era para él ese límite actual, «comienzo del futuro y fin del pasado» ${ }^{39}$, de modo que se producía una comunión entre lo abstracto y lo físico por la cual el «ahora» escandía o medía realmente el movimiento 40 . Ubicándose, al contrario, en el continuo mismo y sin tomar ninguna porción limitada de antemano, Crisipo ya no puede, por análisis, encontrar ningún instante que «agarre» o «muerda» sobre lo real: el «ahora» estoico no realiza, no escande el tiempo en tramos sucesivos, y será necesario acudir al testimonio de la sensación (y sólo a él) para captar el presente móvil de los seres reales sobre el cual aportar posterior y derivadamente una medida al modo de un intervalo extenso (particular reencaje de la Lógica en la Física al modo de un sobrevuelo). Los estoicos son los primeros en pensar algo parecido a una «forma vacía del tiempo» al modo en que Kant lo hará siglos más tarde, si bien sólo lo hacen para despojarla de toda realidad y capacidad de influencia sobre los cuerpos, y en esto siguen siendo plenamente antiguos.

Otro texto traído por Ario Dídimo, esta vez de Posidonio, viene a arrojar luz sobre la distinción entre el tiempo del pensamiento y el presente de la sensación. Ario nos ha transmitido un poco antes que «ningún tiempo es rigurosamente presente, pero lo llamamos presente en sentido lato» o «según una cierta extensión». Ahora se especifica que «en sentido riguroso» quería decir «tomado por el pensamiento (noeisthai)», mientras que «en sentido lato» o «según una cierta extensión» implicaba «tomado por la sensación (aísthesin)»41. En consecuencia, Posidonio concluye distinguiendo dos maneras de referirse al «ahora»: la rigurosa, según la cual el ahora no es parte del tiempo, y la impropia, según la cual llamamos «ahora» a la extensión de tiempo sensible más pequeña. Si recordamos que según los estoi-

\footnotetext{
39 Física IV, 13, I.

40 En Aristóteles, el «ahora» es el garante de la continuidad del tiempo, aportando el contacto y límite común necesarios en la división actual entre el antes y el después a la que procede un acto de habla. La Lógica queda así naturalmente integrada en la Física (y el tiempo "contagia» su continuidad al movimiento que mide, cf. Metaph. 1071 b). En los estoicos, al contrario, la Lógica nunca mide de este modo real el movimiento (porque tampoco lo divide de modo real; pasado y futuro nunca existen y siempre son infinitos por los extremos), movimiento que no requiere de ninguna contigüidad «lógica» para limitarse, ya que su límite le viene dado de forma inmanente por su propio acto, y la Lógica sólo viene a levantar acta con esa extensión que es su efecto derivado (aplíquese de forma idéntica al lugar, como se ha visto más arriba). Donde Aristóteles puede decir que el tiempo es «número del movimiento según el antes y el después -separados tanto como religados por el 'ahora' que les marca el paso", los estoicos lo definen como mero «intervalo del movimiento», es decir, medida atribuida sólo derivadamente a un movimiento cumplido. Que entre tanto los estoicos hayan tenido que dotar de cierta inteligencia a los cuerpos en la forma del inmanente lógos divino e interiorizar u ocultar una operación que en Aristóteles era puesta al descubierto es algo del todo evidente.

41 Estobeo I, 8, 42 [= 1.105.17W]; Dox. Gr. 461 (Ario Dídimo, fr. 26, fr. 98), en Posidonius, Vol. 3, The translation of the fragments, I.G. Kidd, Cambridge University Press, 1999. Cf. también Goldschmidt, op. cit., § 14.
} 
cos «se llama sensación al soplo procedente de la parte hegemónica» 42 y que en ella el alma no crea de suyo, sino que se limita a otorgar su asentimiento a una representación que imprime en ella lo real ${ }^{43}$, concluimos que quien limita la extensión del presente no puede ser más que un acto real aprehendido por la sensación. Aquí tenemos un principio sensualista que pone en juego toda una teoría del conocimiento en la que la noción de tiempo queda perfectamente integrada.

Para los estoicos, por tanto, la división al infinito se realiza según un método de análisis matemático, «dianoético», que se revela radicalmente incapaz de hacernos apresar los elementos reales de las cosas. Así, no hay problema en aplicarlo ad libitum no sólo a los incorpóreos, sino también a los cuerpos: en ambos casos no se divide más que «en el pensamiento», sin cortar al ente real, como ilustran bien las soluciones estoicas a las paradojas del cono cortado 44 y la dicotomía 45 que tanta perplejidad suscitan en Plutarco y Sexto Empírico. Por eso el tiempo, siendo en esencia un ente de razón, no podría aspirar a «existir» propiamente, esto es, a establecerse en presentes durables y estables de suyo, pues eso sería tanto como decir que un continuo no admite mayor división, lo cual es absurdo en función de su propia naturaleza. Paradójicamente, la particular forma que los estoicos tienen de armonizar su sistema poniendo la Lógica al servicio de la Física les lleva a afirmar que el tiempo durable - presente- es el «real», aunque no sea «propiamente» el que responde a la naturaleza del tiempo. Se da así una distinción entre un tiempo real pero impropio (sensible o incorporado) y un tiempo propio pero irreal (pensable o desincorporado) que es explotada polémicamente por Plutarco y ha terminado por confundir a algunos comentaristas. Y el vacío (infinito por todas partes) es al tiempo (infinito en cada una de sus extremidades) lo que el lugar (limitado) es al tiempo (limitado, es decir, midiendo un presente).

\section{DL VII, 52.}

43 Cf. DL VII, 45-46.

44 Plutarco, Nociones comunes, 39 (1079 D), según la cual son irreales los discos innumerables en los que Demócrito descompuso el cono, de lo que no cabe concluir que el cono mismo no exista. Tomarlo todo por una superficie continua infinitamente divisible, en efecto, es propio del pensamiento, pero no da cuenta de las cosas corpóreas-sensibles, que son las que ostentan el título de reales.

45 Cf. Plutarco, Sobre las nociones comunes, Contra los estoicos, 1082F, y notas 372 y 373 de Raúl Caballero. La solución estoica consiste en afirmar que el movimiento de un cuerpo se produce «como si cubriera de forma compacta [es decir, indivisible y simultánea] el intervalo divisible en una sola e idéntica fracción de tiempo» (Sexto Empírico, Adv. Math., X, 123 [SVF II, 491a]), sin tener que atravesar las infinitas divisiones que el pensamiento atribuye equívocamente a dicho espacio real como si preexistieran al movimiento de las cosas (Zenón de Elea) y sin aceptar tampoco la solución aristotélica (Física, VIII, 363 b 3 y ss.) tácitamente adoptada por Plutarco, consistente en sostener que el móvil «recorre un infinito accidentalmente» en una sucesión continua de antes y después escandidos por el «ahora». En este sentido, véase también la alusión al ejemplo de la gota de vino que se diluye y fusiona con todo el océano (1078D-E y DL VII, 151), que conecta la cuestión del movimiento con la mezcla total de las sustancias mediante la noción de coextensión (antiparéktasis), clave para entender la solución estoica a las objeciones planteadas contra el lugar como intervalo en el libro IV de la Física. 
Que esta multivocidad del tiempo (chrónos, ya infinito o presente) sea achacable a cierta «negligencia terminológica» 46 es debatible, aunque no debemos perder de vista que mientras las teorías del vacío y el lugar habían sido ampliamente desarrolladas con anterioridad, en lo que al tiempo se refiere los estoicos aportan soluciones muy nuevas que carecían de una tradición léxica estable (más allá de términos como el «ahora» y la división gramatical en pasado, presente y futuro). Algo que debemos dejar claro en todo caso es que no hay evidencia en la Estoa Antigua de un uso marcado de aión y chrónos para apelar a los equivalentes crónicos del vacío y el lugar (postura adoptada por Gilles Deleuze en Lógica del sentido), pues el término aión (grosso modo: «eternidad») no aparece empleado en los textos conservados (más bien se alude al «tiempo todo» o «infinito en pasado y futuro»), y sólo lo encontramos usado en las tardías Meditaciones de Marco Aurelio (cuatro siglos posteriores), donde sí da la impresión (aunque nunca de modo concluyente) de ser usado para referirse a la infinitud del tiempo noético como opuesto a las duraciones parciales de un chrónos vital ${ }^{47}$. Más aún, resulta improbable, a tenor de una observación etimológica documentada por Varrón en la que atribuye a Crisipo la definición de aión como «siempre existente» (aei ón) ${ }^{48}$, que los primeros estoicos se sirvieran de este término para referirse a los incorpóreos, a menos que lo hicieran valiéndose de una extrema ironía (no se olvide que Aristóteles había atribuido este eminentísimo «siempre» a los seres ideales que «no están en el tiempo» y cuyos contrarios no podrían darse, como los de la Geometría ${ }^{49}$ ). Más razonable, puestos a distinguir términos, habría sido quizá emplear oúpote («nunca») como equivalente crónico del vacío y dejar aión para la divinidad corpórea y su presente cósmico ${ }^{50}$.

Sea como fuere, ni la frugalidad terminológica de la vieja escuela ni las elocuentes licencias de los autores modernos (y, según parece, también al menos de

\footnotetext{
46 Goldschmidt, op. cit., § 15.

47 Victor Goldschmidt ha sostenido el uso marcado de aión en Marco Aurelio. En su contra sólo cabe esgrimir decididamente el epígrafe 10.31, donde se usa la expresión ápeiroi chrónoi, y quizá el 10.17. Por lo demás, es cierto que chrónos siempre es usado para referirse a una duración limitada. Aión, por su parte, a veces sí es claro que se opone a chrónos, pero en muchas otras, como en 10.5, parece sinónimo de un ciclo cósmico (el de Zeus) y no de un abstracto tiempo ilimitado. Y éste es el problema. A favor de Goldschmidt, en 5.32 parece distinguirse nítidamente aión de los ciclos, y en 11.1 se asocian claramente vacío y aión. En 12.32, finalmente, parece explicarse el reparto crónico del aión en ciclos. 48 «Quod Graeci aiona, id ait Chrysippus esse aei on», De Lingua Latina, 6.2 (SVF 2.163), citado por Sellars, art. cit.

49 Phys. 221b-222a. Sobre el surgimiento de este «siempre», cf. García Calvo, Contra el tiempo, Zamora, Lucina, 2001, p. 163.

50 No parece obstáculo para ello el problema de si entre ciclo y ciclo (y, en concreto, en el límite de la diakósmesis o vaciamiento) el cuerpo del cosmos (y, por ende, su fuego divino) llega a extinguirse por completo o algo de él se conserva (lo cual parece más plausible), pues el «siempre existente» haría referencia no tanto a una infinita extensión temporal cuanto a un modo de ser propio del agente al que nada le es ajeno.
} 
Marco Aurelio) deben servir como coartada para eludir la cuestión esencial, y es que hay de hecho una doble lectura del tiempo en el estoicismo: una para el tiempo como incorpóreo puro y otra para el tiempo como incorpóreo incorporado.

VII. El paralelismo se extiende todavía al cuarto de los incorpóreos, el «expresable» (lektón, a veces traducido por «enunciado»), como podemos adivinar por la cita de Ario Dídimo recogida al principio de este trabajo: «[para Crisipo] sólo el presente existe (hypárchein); el pasado y el futuro subsisten (hyphestánai), pero no existen en modo alguno, como se dice también [cursiva nuestra] que existen en calidad de predicados sólo los atributos actuales; por ejemplo, el pasear se da en mí cuando paseo, pero no cuando estoy recostado o sentado». El expresable comprende en el estoicismo predicados y proposiciones que son efectos o resultados de acciones (no de cualidades intrínsecas de los cuerpos), expresándolas típicamente por medio de verbos. Refleja así acontecimientos que son atribuidos a los cuerpos con verdad o falsedad en función de las acciones puntuales de estos. No es difícil adivinar entonces que el presente de un cuerpo existirá (hypárchein) conteniendo un acontecimiento incorporado y verdadero (el que se está desarrollando ahora, como «leo un artículo»), mientras que el pasado y el futuro subsistirán (hyphestánai o hyphestekénai, modo de ser que conviene propiamente a todos los incorpóreos) conteniendo los acontecimientos que ya han acabado o que aún no se han producido, y que por tanto carecen de la presencia-existencia y el valor de verdad que les aportaría su incorporación. A la más amplia escala (la cósmica de Zeus-Día) «el tiempo en su conjunto es presente» (Apolodoro ${ }^{51}$ ), y cabe suponer que en él todo ocurre bajo la forma de un gran acontecimiento que los abarca a todos (a Zeus se le conoce, no en vano, como el Gran Incorporador debido a la extrema dilatación de su presente). Ahora bien, en la medida en que los seres vivos somos distensiones parciales de Zeus, nuestro presente queda circunscrito en cada caso por los límites de nuestra acción y percepción, y pese a que sepamos que hay un Destino que religa todas las causas y una Providencia que garantiza su ordenación en base a la ley divina, no nos está permitido inferir causalmente unos acontecimientos a partir de otros si no son estrictamente presentes.

En este punto vuelve a entrar en juego la radical brecha ontológica que separa a los incorpóreos de los cuerpos, impidiendo cualquier vinculación causal, ya sea entre los dos ámbitos o entre los propios incorpóreos: la necesidad no «agarra» allí donde no hay sustrato corpóreo que la sostenga («todo el futuro es incierto», Séneca52). Émile Bréhier ha expuesto el modo en que toda la dialéctica estoica se centra en el synemménon como vínculo hipotético homologado a la simultaneidad. Debido a la extrema pobreza ontológica de su objeto de estudio (los expresables

\footnotetext{
51 En Ario Dídimo, 26 (Dox. gr., 461, 10).

52 Consolación a Marcia, XXIII (trad. cast. María Zambrano, El pensamiento vivo de Séneca, Madrid, Cátedra, 1987, de donde tomo todas las citas subsiguientes del mismo autor).
} 
como acontecimientos, incorpóreos e inactivos), la dialéctica no puede pretender sustituir lo verdadero por lo necesario en sentido peripatético, es decir, fundado sobre una inclusión de conceptos ${ }^{53}$. Un acontecimiento puede ser verdadero o falso en la medida en que pertenezca o no a un cuerpo, pero jamás puede pretender arrogarse la necesidad que le atribuyen las oraciones hipotéticas y causales, pues ello supondría otorgarle la fuerza para engendrar su consecuente. En este sentido, en la proposición causal (aitiôdes), como «puesto que es de día, hay claridad», el primer término es llamado analógicamente «como-causa» (o "casi-causa», oionei aítion) para ilustrar su esterilidad e impotencia sobre lo real54. A menudo, de hecho, los estoicos proponían transformar estas expresiones causales en conjuntivas del tipo «es de día $y$ hay claridad» 55 .

La teoría de la interpretación de los signos, sobre la que pudo apoyarse todo un arte de la adivinación, viene a incidir en este aspecto: allí donde los estoicos no podían sumergirse en el pasado o aventurarse al futuro a través de un análisis lógico de la causalidad ni recurrir a la distinción aristotélica entre acto y potencia para reducir el pasado y futuro a concepto ${ }^{56}$, suplieron esta carencia por medio de una

53 «Mientras que los géneros y las especies, en Aristóteles, siguen siendo en cierta medida seres reales, y el pensamiento lógico penetra en las cosas mismas, los expresables no contienen nada en su naturaleza y por consiguiente no transportan nada en el pensamiento de la naturaleza real de la que son los productos y los efectos», Bréhier, op. cit., p. 34.

54 DL VII, 71. Cf. también Clemente de Alejandría, Stromata VIII, 9 (SVF II, 119, 41): «los estoicos dicen que el cuerpo es causa en sentido propio, pero el incorpóreo, de un modo metafórico y como al modo de una causa (aitiodôs)», y Séneca, Cartas a Lucilio, ep. XIII: «¿Es verosímil un mal futuro? De aquí no se deduce que sea verdadero. [...] Si aún no ha sobrevenido el mal, ¿de qué sirve anticiparlo?»

55 Cf. el debate sobre la libertad recogido por Cicerón (De fato, VIII, 15), donde Crisipo propone transformar las condicionales en conjuntivas. El condicional devenido conjuntivo es el modo incorporador del adivino, reductor del tiempo a casi-cuerpo. La línea del tiempo da así la impresión de curvarse y compactarse en una predicción real.

56 Como ha mostrado A. García Calvo (Contra el tiempo, 11) dicha distinción permite a Aristóteles dotar de realidad a las formulaciones en Hipotética Eventual, tan problemáticas por contener una distinción irreductible entre el «habla»y las «cosas» (la paradoja de la condicional, en efecto, es que algo sucesivo en el mundo debe ser simultáneo en el habla). Al trazar, por medio del «ahora», distinciones o cortes actuales entre franjas potenciales del tiempo (futuro, perfecto, imperfecto...) y combinarlas con la pareja «en potencia/en acto» aplicada a las cosas mismas, Aristóteles se permite atravesarlas con los vínculos causales que habían rechazado los Megáricos, cuyo razonamiento heredaron los estoicos. Estos últimos, que como aquellos impugnaban la famosa distinción (cf. Metafísica, 1046 b 29), denuncian presumiblemente el modo en que el aristotelismo «fisicaliza» tramos del tiempo cuya escisión no pertenece más que al habla (es decir, a la Lógica). Su postulado del movimiento como actualidad permanente implica renunciar a esta vinculación: el Destino es siempre presente y exige una identidad de las causas, no una trabazón intertemporal. La causalidad aristotélica, en cambio, escande realmente el tiempo, que se contagia de la división potencia/acto a fin de ser «gobernado» desde los actos de habla. Obviamente, los estoicos emplearán su propia manera forzada de neutralizar el tiempo en los cuerpos con la Providencia y el Destino: al no implicar el movimiento para ellos paso del antes al después, sino presente constante, interiorizan u ocultan la sucesión en el seno de una Física glorificada. 
efectiva dilatación del presente: como «el signo presente debe ser siempre signo de una cosa presente» (Sexto Empírico ${ }^{57}$ ), en una proposición adivinatoria del tipo «si hay una cicatriz, hubo una herida» no se significa tanto la herida misma cuanto el hecho presente de «haber tenido una herida», cuyo signo, también presente, es el hecho de «tener una cicatriz» ${ }^{58}$. En el presente, el antecedente y el consecuente se aproximan tanto como les es posible a la identidad, que es el único modo de vinculación entre acontecimientos (precisamente por dejar de ser propiamente una vinculación a través de tiempos distintos). Cuando el adivino busca señales en las vísceras de animales, debemos entender que busca no acontecimientos pasados o futuros causalmente determinados, sino ya de algún modo presentes en la naturaleza de los cuerpos: el Destino no es el vínculo necesario de los acontecimientos entre sí, sino la unidad de las causas entre sí (a pesar de que, como efecto de la vinculación de las causas, los acontecimientos se contagien de la héxis física de todas las partes del cosmos y se desenvuelvan unos a continuación de otros en una cuasi-héxis lógica59). A este riguroso nivel causal de los agentes corpóreos, no ha de decirse que la sucesión temporal despliega un conjunto inicialmente dado o preexistente en la mente de Dios, sino que más bien los fragmentos de tiempo y la sucesividad sólo son ilusiones derivadas de una percepción parcial: al Destino no se accede por un largo peregrinaje temporal o un acceso privilegiado a un plano trascendente, sino por una ampliación de escala (casi diríamos: zoom out) en la que los presentes parciales quedan absorbidos en el presente total de un ciclo cósmico al que trata de acceder el intérprete.

VIII. La impugnación del «realismo» se da entonces a los tres niveles de la Lógica: al nivel del espacio, el lugar niega los límites inmanentes al vacío y cualquier carácter físico de contigüidad al intervalo; al nivel del tiempo, el «ahora» sabotea todo segmento inmanente o parte estable del tiempo infinito, así como su propia capacidad para escandir o articular el movimiento; finalmente, al nivel de los expresables, el carácter incorpóreo del acontecimiento rompe tanto la necesidad que lo vincularía con otros acontecimientos a través de los tiempos verbales como cualquier forma de causalidad entre atributos y cuerpos. En los tres casos, sólo se dice del lugar, el presente y el acontecimiento actual que existen o son reales en un sentido impropio y en la medida en que quedan determinados o incorporados 60 .

\footnotetext{
57 Adv. Math., VIII, 244 (SVF II, 73, 24).

58 Cf. Bréhier, op. cit., p. 32.

59 Este tema, el del Destino frente a la necesidad, es el que ocupa a Cicerón en De Fato, sin que él dé la sensación de resolverlo satisfactoriamente.

60 En un sentido propio y riguroso, habría que decir que los incorpóreos sólo subsisten. Si se dice que «existen» es porque señalan o sobrevuelan un cuerpo, su disposición o una cualidad corpórea. Y lo mismo ocurre a la inversa: los acontecimientos no determinan ni caracterizan al tiempo en sentido estricto (no lo «individúan» al modo escolástico) porque la causa corpórea a la que son referidos no posee la capacidad de «realizar» a una casi-causa. La brecha ontológica siempre se mantiene abierta e insalvable, lo cual contribuye a hacer compatible el eterno retorno con la libertad, pues no hay nada
} 
Llevada al extremo, la escisión ontológica entre Lógica y Física deriva en el establecimiento de dos tipos de conocimiento totalmente distintos: uno, la representación sensible, que tiene por objeto las acciones de los cuerpos y «nunca acaba de encontrar su expresión en el lenguaje» ${ }^{61}$; otro, las elucubraciones del pensamiento, que se centran en los atributos expresables y no cargan con nada de la naturaleza real de la que son las meras manifestaciones impasibles. A este respecto, es muy significativo que la Lógica no sea para ellos un órganon de la Filosofía, y ni siquiera una porción orgánica integrada en ella (mórion), sino sólo una parte (méros) ${ }^{62}$. Necesaria, sin duda, para alcanzar la plena funcionalidad y armonía del sistema (los incorpóreos, incluso los más ajenos a la realidad, como el vacío y el tiempo infinito, son necesarios para entender y explicar el movimiento en la medida en que el mundo real es inseparable de un proceso de incorporación), pero en una situación muy diferente a la del aristotelismo, donde Lógica y Física aparecían complicadas entre sí de forma decisiva, hasta el punto de volverse prácticamente indiscernibles.

\section{Tiempo y materia: la Ética estoica}

IX. Pero seríamos injustos con el estoicismo si nos limitásemos a exponer la doctrina del tiempo desde las perspectivas lógica y física, por más que en ellas hayamos disipado la plutarquiana contradicción inicial con que comenzaba este artículo. La escuela nunca ocultó su vocación terapéutica ${ }^{63}$, lo cual implica de algún modo que lo que se ha sembrado en Lógica y Física debe ser recogido en la Ética con una doctrina de la felicidad íntimamente asociada a la noción de tiempo. Si Émile Bréhier es el autor de referencia a nivel de la Lógica y los incorpóreos, Victor Goldschmidt es quien mejor ha sabido exponer el aspecto ético del estoicismo. Para ello ya no se apoya en los textos de la Antigua Estoa, sino en autores tardíos, y especialmente en Epicteto y su discípulo Marco Aurelio. Es posible que al proceder así haga pasar una evolución interna de la escuela por una sistematicidad en exceso forzada, pero ante la tesitura de tener que elegir entre reducir cada sutileza a un «añadido» o presentar un exceso de sistematicidad a fin de salvar la coherencia, parece

\footnotetext{
que nos obligue a aceptar lo que viene después por muchas veces que haya sucedido antes. En este sentido, cf. Marcelo D. Boeri, «Incorpóreos, tiempo e individuación en el estoicismo», en Dianoia, 51, noviembre 2003, pp. 181-193.

61 Bréhier, op. cit., p. 62.

62 Cf. Amonio, Comentario a los An. Prim. de Aristóteles, 8, 20, así como 9, 1 (SVF II, 49, en Crisipo de Solos, Física estoica, recopilación de Adrián Castillo, http://galileo.fcien.edu.uy/ Grisipo_de_Solos_-_Logica_Estoica.pdf). Para una comparación similar y muy significativa, cf. DL VII, 40: «Comparan la filosofía [...] a un huerto frutal: la valla que lo rodea es la lógica, las frutas son la ética, y la tierra y los árboles la física».

63 Cf. DL VII, 7 y 9; Séneca, De la constancia del sabio, I y XIII; De la vida bienaventurada, III; Cuest. naturales, II, LIX.
} 
obvio con qué es preferible quedarse en virtud de un irrenunciable sentido de la armonía filosófica y cierta confianza en la vocación estructural y arquitectónica de los pensadores antiguos. Después de todo, no sólo es innegable que estos autores manejaron los textos y el aparato conceptual de la Antigua Estoa, sino que su fidelidad a los mismos permite al historiador reconstruir, a partir de sus originales reflexiones de índole ética, el sentido de ciertos planteamientos oscuros en los campos de la Lógica y la Física. El veredicto, por tanto, ha de ser que en los cinco siglos de evolución de la escuela no se produce una decadencia tan significativa como para impedir tratar el estoicismo como un bloque sistemático, e incluso, parafraseando a Goldschmidt, como la filosofía más sistemática de la Antigüedad.

La doctrina de la felicidad comienza allí donde se revela la incapacidad del adivino para abrazar el Destino a través de la búsqueda de señales inscritas en los cuerpos. Pese a que la interpretación de los signos pueda alcanzar cierto rendimiento en la ampliación del presente, en última instancia se enfrenta a una tarea imposible, pues a un agente cualquiera la inmensidad del espacio y el tiempo no le es dada, en cada ocasión, más que en este lugar que ocupa y en este presente en el que actúa y percibe. El adivino trataría en vano de procurarse un presente cósmico a través del estudio de señales: el acceso a la unidad de las causas es patrimonio exclusivo de la visión divina, que abraza o absorbe el encadenamiento sucesivo de los cuerpos. La única forma de verlo todo sería durar y medir tanto como Dios, pero no es la duración ni la extensión cósmicas lo que convertirán en «divino» al sabio, sino que habrá que buscar el acceso a la felicidad por una vía totalmente diferente ${ }^{64}$. A este respecto es significativo, pese a tratarse sin duda de un caso extremo, el testimonio sobre Aristón de Quíos, discípulo de Zenón y miembro de la Antigua Estoa, que aporta Diógenes Laercio: «Rechazaba el estudio de la Física y el de la Lógica, alegando que aquélla está más allá de nosotros y ésta no es nada para nosotros; sólo la Ética es lo que nos afecta» 65 .

Si para los estoicos es tan importante la doctrina de la felicidad es porque sienten que el acto vital de los seres racionales está cercado por una doble amenaza que pone en peligro su delicado equilibrio; la Ética resulta inseparable de un acto de resistencia. La primera de esas amenazas, lo hemos visto, procede del pensamiento (diánoia) y es la creencia en una determinación que el acto vital recibiría de un ámbito ideal trascendente, ahora reducido al dominio de una Lógica impasible. La segunda, más inopinada pero a nuestro entender muy ostensible en los textos, pro-

64 «Pero yo, me digo, no soy capaz de seguir a la vez todas estas cosas. ¿Y quién te dice eso? ¿Quién te dice que no tienes un poder igual al de Zeus?» (Epicteto, Diss., I, XIV, 11-12, citado por Goldschmidt, op. cit., p. 73); «No consiste la felicidad en que se te dilate el día de la muerte; porque aunque la dilación hace que la vida sea más larga, no hace que sea más dichosa» (Séneca, De los siete beneficios, V, XVII).

65 DL VII, 160, 161. 
cede del principio pasivo inscrito en el seno material de los propios cuerpos: «el principio paciente es una sustancia sin cualidad, la materia, y el agente es la razón ínsita en ella, la divinidad. Pues ésta, que es eterna, a través de toda ella modela todas las $\operatorname{cosas} » 66$. Pese a su proverbial materialismo, los estoicos atribuyen toda la dignidad de los cuerpos no a su materialidad, sino a la inteligencia divina ínsita en ellos al modo del principio activo y corpóreo que los vincula. La fórmula sería entonces: cuerpo individual $=$ materia + pneûma y ser vivo individual $=$ cuerpo individual + alma (principio hegemónico) ${ }^{67}$.

En lo que los cuerpos siguen teniendo de principio pasivo (materia), y aunque esta distinción sea tan sólo accesible al pensamiento (kat'epínoian) ${ }^{68}$, son vulnerables a las afecciones de lo fantástico y los fantasmas. Según Crisipo, «lo fantástico (phantastikón) es un movimiento vacío, porque la afección no es producida en el alma por ningún objeto real, precisamente como ocurre con el que pelea con sombras, lanzando golpes al vacío. En efecto, a la fantasía [o 'representación'] subyace algo que la produce, pero a lo fantástico nada» 69 . Y «fantasma (phántasma) es aque-

66 DL VII, 134, 150 («Cuerpo es, según ellos, la sustancia delimitada»). Nótese que los estoicos distinguen entre principios y elementos. Los primeros, activo y pasivo (inteligencia divina y materia fluyente e inasible), son «eternos e indestructibles», mientras que los segundos, fuego, aire, agua y tierra, son resultado del proceso de diakósmesis (distensión o extinción) y «se destruyen en la conflagración ígnea» (culminación del proceso de signo inverso) que retrotrae periódicamente el cuerpo del mundo a fuego primordial.

67 Como se deriva de la corporeidad universal de los seres reales en el estoicismo, la distinción entre cuerpo y alma no es de naturaleza, sino de grado de distensión del fuego primordial. Cf. DL VII, 156: «Pero [el alma] es perecedera, mientras que el alma universal es indestructible, y de ella son partes las almas de los seres vivos». Nótese que aquí lo perecedero es la distensión parcial del alma universal, que es reabsorbida finalmente en la totalidad del fuego primordial o alma de Zeus (también corpórea, pero imperecedera). Igualmente, hay que marcar bien la distinción entre el pneûma que cohesiona y cualifica a los seres compuestos en general (ver nota 22) y el alma de los seres vivos dotados de percepción y sentidos (animales, hombres y dioses). Cf. notas 187 y 350 de R. Caballero a Plutarco, Contr.

68 La difícil noción de «principio» en el estoicismo ha generado multitud de ataques por parte de sus rivales (Plotino, En., VI 1, 27, y Plutarco, 1086A-B, entre otros). La dificultad reside en su asimetría: mientras el principio pasivo es materia fluyente no cualificada (es decir, sub-corpórea), el activo sigue siendo corpóreo (pues de otro modo se incurriría fatalmente en platonismo), por lo que contiene en sí al pasivo, volviendo paradójica la clasificación. La razón de esta marcada anomalía es que, mientras la materia es una abstracción accesible sólo al pensamiento, el principio activo (fuego primordial o inteligencia divina), por ser real, ha de ser doble. Se da así un paralelismo, al nivel sub-real, con la imposible clasificación supra-real de los seres y los incorpóreos en la categoría del «algo» (ver nota 16), y con la de Todo (tó pan) que engloba el universo y el vacío circundante (Plutarco, Noc. Com., 30). Es verosímil que Crisipo empleara estas paradójicas categorizaciones para ridiculizar la pretensión de recoger la realidad en géneros lógicos y primar la sensación como modo de acceso a lo real. ${ }^{69}$ Aecio, Opiniones IV, 12, 1. (SVF II, 54). Empleo la traducción de A. Castillo, aunque quizá se podría emplear el término «fantasmático» en lugar de «fantástico» para acentuar el carácter inexistente de esta afección, quedando entonces lo «fantástico» como lo propio de la phantasía, que es la afección producida en el alma por algo real -el phantastón o lo imaginado-y ya no irreal -el phántasma-). 
llo según lo cual somos arrastrados en la aprehensión vacía de lo fantástico. Esto ocurre en el caso de los afectados por la bilis negra y los maníacos»70. Estos fantasmas parecen ser las marcas de acciones pasadas o expectativas futuras que encuentran la manera de instalarse en el presente, que es el único tiempo de la acción corpórea. Pueden tener causas como la bilis de Orestes, pero en otros casos la afección es de un tipo anímico ${ }^{71}$, como en el caso del atormentado al que alude reiteradamente Marco Aurelio: aquel que se ve permanentemente abocado a esperar el futuro o lamentar el pasado como si fueran franjas de un tiempo existente. Si se busca la causa profunda, ontológica de estas pasiones («movimientos irracionales del alma en contra de la naturaleza»o «impulsos excesivos», según Zenón ${ }^{72}$ ) más allá del evidente «juicio errado» (y no dudamos que la Filosofía deba hacerlo, pues si bien el error pretendería realizar lo ilusorio, él mismo es persistente y exige ser fundado), parece detectarse en ellas una componenda dañina entre las ilusiones de permanencia de un tiempo abstracto y la pasividad de la materia que las acoge, como si ésta fuera la vía de infiltración (y no el origen, a diferencia del platonismo) en el presente de todas las ilusiones lógicas y dialécticas de un tiempo, un espacio y una serie de acontecimientos parcelados en segmentos estables. El preocupado (afligido de pena, temor, deseo y placer), no hace así más que anhelar o lamentar, perdiendo por completo las riendas del único tiempo del que es dueño por causa de una enfermedad (de origen material o noético, pero somatizada en cualquier caso) que lastra su acción y altera su representación hasta ser movido por una tracción vacía hacia un objeto inexistente. Los fantasmas del estoicismo son siempre cuasi-seres (acontecimientos, tiempos y lugares no actuales) infiltrados en el presente a través de la puerta trasera de la pasividad material (en este sentido, es muy reveladora la afirmación de Crisipo de que la división de la materia es infinita, pues viene a confirmar el estrecho paralelismo con los incorpóreos de superficie ${ }^{73}$ ). Se da así una

\footnotetext{
70 Ibid.

71 «Como se habla de algunas enfermedades del cuerpo, como la gota y la artritis, así también las hay en el alma, como el afán de gloria y el amor del placer y las parecidas [...]. La dolencia es la suposición de algo como extremadamente deseable» (DL VII, 115). Lo que parece producirse en ambos casos es una descomposición de la héxis que mantiene cohesionadas las partes en la unidad del presente: a una acción descompuesta por una tracción hacia lo inexistente corresponde un cuerpo que pierde la fuerza de su lazo interno, disgregándose en una suma de pedazos yuxtapuestos y contiguos. 72 DL VII, 110.

73 DL VII, 150. Materia e incorpóreos tienen en común ser atributo irreal de los cuerpos. En DL VII, 134 incluso se llega a decir abiertamente que «los principios son incorpóreos» (trad. Carlos García Gual), lo cual no parece armonizar muy bien con la realidad del principio activo (fuego primordial) pero sirve para confirmar la caracterización de la materia como una suerte de incorpóreo (o, al menos, lo amorfo) de profundidad. En este sentido, en la solución a la aporía de Aquiles y la tortuga (ver nota 45) se aprecia bien que si no fuera por la inteligencia divina que otorga a la materia intervalos reales no habría movimiento posible. La materia y el pensamiento, en efecto, sabotean el movimiento; una, dejándose dividir al infinito; el otro, dividiéndola, y es sólo el principio activo quien impide esa desmesura.
} 
alianza subversiva entre lo profundo y lo elevado, entre lo viscoso-descualificado y lo ideal, que trata de socavar el frágil equilibrio de la salud corpórea y hace aflorar una tensión no resuelta en el seno de la ontología estoica74.

El presente arrastra entonces la inhabitable demencia de un tiempo sin cuerpo y se ve secuestrado por un pasado que nunca pasa y un futuro que nunca llega (los lamentos y los anhelos, aunque haya otras formas de acceder a la fiebre aiónica, como la del que inicia o interrumpe sus acciones en base a un tiempo ilegítimo -el de las clepsidras- o una falsa división de lugares - la de las ciudades y provincias ${ }^{75-)}$. Este tiempo pasivo-estructural (por cuanto, en lugar de pasar, conserva adheridas sus partes ficticias) es la definición misma de la enfermedad anímica para los estoicos («ia cuántos ambiciosos pensamientos no le impulsa el olvido de su condición? Lo inmortal e infinito ocupan su mente, ordena el porvenir de sus nietos y biznietos, y en medio de sus proyectos para la eternidad, le hiere la muerte» ${ }^{76}$ ), y la manera de purgarlo no será otra que la de operar en él un exorcismo que le devuelva a su amnésica desnudez original. Goldschmidt ha mostrado aquí un equivalente existencial del método divisor de Crisipo: del mismo modo que, en el pensamiento lógico, las franjas del tiempo eran reducidas a la delgadez abstracta de un instante inextenso (irreal pero propio), los clichés pasionales del necio y su encabalgamiento estructural son reducidos, en la Ética, a la insignificancia de un presente desnudo (impropio pero real) 77 . Devuelto en un primer paso a su grosor mínimo («polvo» o «ceniza» en Séneca y Marco Aurelio) y desconectado de los fantasmas con los que pretendía formar bloque y hacerse «parte del tiempo», el presente es purgado de pasión y arrojado a un estado de extrema indefensión ${ }^{78}$ que, no obstan-

\footnotetext{
${ }^{74}$ Los presentes parciales, como los cuerpos, se reabsorben cabalmente en la mezcla total, pero los clichés pasionales del necio pretenden que su parcialidad crónica se resuelva en una sucesión lineal. La enfermedad es la sustitución de la distensión por la sucesión (entiéndase: se sucede lo dividido y yuxtapuesto, no lo distenso), y la tenaz recaída de los seres en esta ilusión dañina sólo parece explicarse por la oposición entre el principio activo tonal-abrasivo y el principio pasivo infinitamente divisible inscrita en la intimidad de los cuerpos. En este sentido, sólo la Ética permitirá poner a cubierto la fragilidad física de los seres ofreciéndoles un alivio de la parcialidad.

75 Recordemos la invitación de Epicteto a sus alumnos a proclamarse ciudadanos de un mundo regido por la Providencia (Disertaciones, I, IX, 8, citado por Goldschmidt, op. cit., p. 71), así como la elocuente Consolación a Helvia de Séneca: «Marcelo soportó, pues, sabiamente su destierro, y el cambio de lugar no alteró nada en su alma», etc. Cf. también Cartas a Lucilio, ep. XXIV: «¿Desterrado? Supondré que he nacido allí donde me manden», y XXVIII.

76 Séneca, Consolación a Marcia, XI; cf. también Cartas a Lucilio, ep. XIII.

77 Goldschmidt, op. cit., pp. 168-186. Cf. Marco Aurelio, 11.2, 2; 5.24, 4.48 o 4.50.

78 En este punto adquieren su sentido terapéutico los célebres pasajes «heracliteanos» de Marco Aurelio: «el tiempo es como un río de sucesos y un flujo violento. En cuanto algo se ve, ya ha pasado de largo y otra cosa distinta es la que pasa, que también pasará» (4.43; cf. también 5.23 y 6.15), así como la figura del «inquieto perezoso» de Séneca, distinguido del «inquieto loco» (De la tranquilidad del ánimo, XII). Cf. también Cartas a Lucilio, ep. XLIX: «Infinita es la velocidad del tiempo, y se nota mejor cuando se mira hacia atrás, porque el presente escapa a los que quieren considerarlo: tan rápida es su fuga».
} 
te, permitirá operar en él el segundo paso: la recuperación de un auténtico presente activo 79 .

En este punto, sin embargo, algo muy nuevo acontece: asomado a la subsistencia rigurosa del tiempo, el sabio accede al misterio de la incorporación y mantiene su presente circunscrito a la mínima extensión necesaria, la única capaz de garantizarle protección frente a los fantasmas del pensamiento y esa tozuda creencia en bloques de tiempo o cadenas de acontecimientos que requerirían de la sucesión para realizarse. Desde entonces no vivirá más que un ahora extenso pero mínimo (según la segunda acepción de Posidonio), aquel capaz de incorporar en cada caso el lugar, el tiempo y el acontecimiento que aferra ${ }^{80}$. Al enigma del enfermo -padecer un instante inextenso como duración presente-, se le opone el contraenigma del sano -vivir una duración como instante mínimo-. En esta delgadez salvífica, austera pero vital, el sabio vive permanentemente la ocasión propicia y nada más que ella (la eudaimonía estoica es una eukairía), por lo que resultará de suma importancia distinguirse a sí mismo como agente del acontecimiento, el lugar y el tiempo que encarna a fin de no claudicar su valiosa autosuficiencia ${ }^{81}$. El símil con el actor de teatro de Aristón, retomado y ampliado presumiblemente por Epicteto, es muy significativo. Al hablar de la indiferencia del sabio ante las cosas que no son ni virtuosas ni viciosas, Aristón comparaba al sabio con un «buen actor, que tanto si representa el papel de Tersites como el de Agamenón actúa de uno u otro convenientemente» 82 . En unas páginas de gran belleza, Goldschmidt comenta los pasajes de Epicteto contraponiéndolos a la concepción platónica de la tragedia: «según Platón, el actor recibe necesariamente en su alma los defectos de los personajes que haya representado, mientras que, según Epicteto, el actor, por definición, mantiene su papel a distancia; así, para reducir al absurdo al alumno que viene a decirle: 'Cámbiame el tema', Epicteto le responde con sorna: 'También llegará el tiempo en el que los actores creerán que sus máscaras, sus zapatos y su trajes son ellos mismos'»83. Si el personaje desborda su presente por sus recuerdos, remordimientos,

\footnotetext{
79 Me parece que la discusión de Pierre Hadot con Victor Goldschmidt (The inner citadel, Harvard University Press, 1998, p. 137) puede resolverse aclarando que el paralelismo entre los métodos de división lógico y existencial no implica que el resultado del segundo haya de ser también un instante abstracto. Cf. Séneca, Cuestiones naturales, VI, XXXII: «No me pertenece el porvenir ni el pasado. Estoy suspendido en un punto móvil del tiempo fugitivo; y mucho es ya estarlo un poco» (cursiva nuestra).

80 «Y juntamente con la gallardía de ánimo hará que ninguna cosa de las que en la vida suceden le sea repentina», Séneca, De la tranquilidad del ánimo, XI.

${ }^{81}$ Hay, por lo demás, una correlación profunda en el estoicismo entre el descubrimiento de un tiempo vacío y la conciencia profunda de un «mí mismo». Si algo les impidió ser plenamente modernos fue, sin duda, su resistencia a aceptar un «Yo pienso» (esto es, una Lógica) capaz de ser determinante y cargar con el peso del sistema.

82 DL VII, 160.

83 Epícteto, Dis., I, XXIX, 41, citado en Goldschmidt, op. cit., p. 181.
} 
miedos o esperanzas, el actor virtuoso vive guarecido en la perfección de su «ahora», y allí donde el papel de teatro exige tiempo para ser recitado, el actor puede alcanzar la perfección de su arte aunque no concluya la función 84 .

Si el estoicismo es ajeno a toda distancia en el sentido de una espera que haría desenvolverse paulatinamente a los acontecimientos (a los que sería preciso atender -exspectare- pasivamente), es porque en él la felicidad plena puede guarecerse en otro tipo de distancia activa que casi podríamos llamar «trascendental»: la que se da entre el agente y lo que ejecuta a cada instante. Este actuar con desapego (híleos en Marco Aurelio ${ }^{85}$ ), aceptando los acontecimientos conforme se producen y sin precipitar ni postergar su llegada, implica no perder jamás de vista la distancia cabal que separa a la Lógica de la Física conteniendo los abusos a que el pensamiento y la materia querrían someter al agente corpóreo. Puede que no estemos lejos de entender la forma en que todo el sistema conspira hacia la figura del sabio feliz si definimos la Ética estoica como la plena conciencia de esa distancia o escisión. Y quizá, por otra parte, no nos apartemos mucho de la idea estoica de felicidad y su relación con el tiempo si pensamos en la figura de un tocadiscos donde la superficie del plato que gira indefinidamente (y de la que el disco obtiene su movimiento) es el flujo de los acontecimientos en un tiempo infinito. Allí donde el adivino o el profeta pretenderían ir del presente cósmico (la visión del disco con todas sus canciones) al acontecimiento aún no efectuado (una de las canciones que aún no han sonado, que queda así integrada y ordenada como la siguiente o la subsiguiente), en el caso del sabio que alcanza la felicidad se va del acontecimiento puro (moverse del plato) a su efectuación presente más limitada (el «ahora» equivalente al contacto de la aguja con la superficie móvil del disco). El agente del Destino no es entonces quien conoce o comprende de antemano el disco en su totalidad, sino el que sabe ser uno mismo la aguja lectora que va encarrilando todos los sonidos conforme vienen y a la velocidad que vengan en el microsurco adecuado. Se dirá de él que no decide el orden de sucesión, que queda delegado en la Providencia, pero a cambio, mientras dura el contacto con la superficie, no hay sonido que se le escape. No le es preciso ser Dios, pues Dios sería el rodillo lector que de una vez abarca toda la superficie del disco ${ }^{86}$, sino ser como Dios o un dios en miniatura ${ }^{87}$, es decir, enten-

${ }^{84}$ Cf. Marco Aurelio, 12.36 y 8.32 («La vida debe organizarse acción por acción»), Epicteto, Manual, XVII, o Séneca, op. cit., IV.

85 «Márchate por tanto de forma propicia porque también el que te libera lo hace propiciamente», 12.36, 5. Cf. también 9.29: «si los platónicos se comportaron como actores trágicos por exceso de ambición, nadie me ha condenado a imitarlos» y 11.3: «no por mera obcecación, como los cristianos, sino tras haberlo razonado, tan dignamente que se pueda convencer a otro y sin hacer de ello una tragedia».

86 Si bien, a su manera, el propio tiempo de Dios es circunscrito por cada uno de los ciclos cósmicos, «momentos divinos» que nunca incorporan plenamente la infinitud del tiempo y el vacío: en este caso, el disco volvería a comenzar tras su finalización. Lo que desde luego no hay en los estoicos es la pre- 
der el pasaje entre el tiempo puro y la acción corpórea en que consiste que algo acontezca, y cómo ese pasaje no sólo no constituye una amenaza para el orden del mundo, sino que el Destino se da, existe, precisamente en la afirmación del tránsito. La dilatación del instante es entonces figurada: se dilata porque coincide, porque es encarrilado en la buena pista, conspirando con el todo y conformándose a él; la felicidad es el milagro panecástico de la comunión en que consiste el auténtico pasar del tiempo ${ }^{88}$. Sólo así se entienden las máximas estoicas en clave moral: «hacer uso del presente», "satisfacerse con la condición presente y gozar de todo lo que llega a ser presente» (Marco Aurelio), «querer los acontecimientos conforme se producen» o «la vida, si sabes usarla, es larga» (Séneca).

\section{Conclusiones. Estoicismo e historia de la metafísica}

$\mathrm{X}$. La primera conclusión que extraemos de este estudio es que la doctrina del tiempo posee coherencia; no sólo se armoniza en dos lecturas, sin que el historiador pueda reducir la una a la otra más que al precio de mutilar la imagen de conjunto, sino que finalmente queda rematada por una doctrina de la felicidad que consiste en entender el singular punto de contacto entre ambas: el momento en que el devenir infinito de la Lógica, que desde luego no está hecho a escala de ningún ser vivo ni es por tanto habitable, queda incorporado, convertido en índice de un acto que le otorga consistencia en el presente. La eukairía del sabio consiste así en aislar la manera en la que un agente «hace suya» la ocasión e incorpora los acontecimientos religando el tiempo mismo en la acción. La dificultad del mandato, y aquello por lo que se dice que el sabio es más raro que el fénix, reside en que esa incorporación debe ser reducida a su grado de máxima pureza: entender lo que podríamos llamar «la forma trascendental del tiempo», es decir, el puro acto de la incorporación, la «actualidad» (o «actidad»), el encaje entre los dos tiempos, más allá de ésta o aquella acción concreta. La felicidad consiste en estar a cada momento, se haga lo que se haga, en posesión del secreto de la incorporación del acontecimiento: cómo el tiempo vacío y la materia descualificada son determinados, anclados a la corporeidad cumpliendo el Destino y abandonando el crudo aspecto de un flujo amenazan-

existencia de un «plan» divino a lo Leibniz o una procesión a lo Plotino; la idea misma de un desenvolvimiento tal (explicatio) implicaría franjas de tiempo y sería contraria a la doctrina.

87 El símil de la miniatura (mikroteknía) viene a conjurar la ilusión de un ensanchamiento cuantitativo de la duración: no se trata de agrandar lo pequeño, sino de empequeñecer lo grande. Véase Séneca, Cartas a Lucilio, citado por Goldschmidt, op. cit., p. 209, así como Epistolas, 53, II: «Es propio de un gran artista tratar de encerrar el todo en un espacio insignificante. El sabio está tan bien en su existencia como Dios en la sucesión de los siglos».

88 Allí donde el profetismo y la adivinación (votos, ofrendas) sólo pueden brindar un alivio de la parcialidad, el sabio debe ir más lejos y encontrar el todo en su parte de tiempo. Es la diferencia ostensible entre soportar el Destino conforme se viene encima y ser el Destino según se crea. 
te y corrosivo; cómo la Lógica es incorporada por la Física, que la llena de sentido, articulando así el movimiento del mundo y resolviendo el enigma del cambio.

XI. La segunda conclusión trataremos de resumirla como sigue. Es cierto que en la tradición griega clásica, y ejemplarmente en Aristóteles, no se piensa el movimiento más que como movilidad del ente. Ahora bien, hay que añadir, más aún, que no se piensa el móvil sin un contorno o límite que posee a cada instante y que va escoltándolo a lo largo de su movimiento. Este límite, el lugar, le acompaña como una sombra familiar, y no hace más que testimoniar el hecho de que concebimos el movimiento en instantes puntuales. La sombra es como una pista de despegue, pues siempre se capta en el trance previo a la fuga del cuerpo (sólo posee un lugar aquello que no deja de perderlo); es el correaje, la estela, el rastro, la sucesión de posiciones estáticas, la fantasmagoría de un movimiento real que no se aprehende más que por sus huellas continuamente borradas: «aquí-y-ahora; aquí-y-ahora; aquí-yahora...» El lugar y el instante están así íntimamente vinculados y se exigen mutuamente: ambos dan testimonio de que el alma no capta el movimiento sin «idearlo», sin reducirlo a una parada, a una instantánea, por transitoria y parcial que ésta sea. El lugar es una exigencia ideativa para pensar el movimiento como detenido (haciéndolo continuo pero divisible), y en este sentido es hermano del «ahora» que aporta su medida. Ambos son ingenios de medición integrados en la percepción natural y deben distinguirse de los cuerpos, no siendo parte de ellos, sino «atributo» ${ }^{89}$. Así es como se consigna en Aristóteles, cumbre del pensamiento realista griego sobre el movimiento, la autonomía y soberanía del móvil en física, como en metafísica de la entidad y en lógica del sujeto. Y todas estas nociones están íntimamente imbricadas y coinciden en hacer un amasijo indisociable entre el habla y el mundo, la Lógica y la Física: un mundo a la medida de seres racionales y una palabra a la medida de un mundo móvil.

Los estoicos parecen querer rebelarse frente a esta realización del pensamiento o ideación de la percepción y escinden Lógica y Física ${ }^{90}$, reduciendo casi cómicamente este contorno noético a un mero acompañamiento inocuo. Al proceder de este modo, sin embargo, y como por una ironía filosófica, necesitan echar mano de un tercer término que cargue con la explicación del movimiento y le haga de principio y causa: este nuevo término es el principio activo, fuego primordial o inteligencia divina, singular lógos ajeno a la palabra, o, más claramente (y empleando deliberadamente un término moderno), la vida que penetra e insufla los cuerpos haciéndo-

\footnotetext{
$89 \mathrm{El}$ «ahora» no es parte, sino atributo del tiempo, y el lugar no es parte, sino atributo del cuerpo. Cf. Victor Goldschmidt, «La théorie aristotélicienne du lieu», p. 55, nota 8.

90 Que esta desconfianza hacia la palabra ilustre el comienzo del declive del pensamiento griego sobre la phýsis queda a la discreción del lector. Es, sin embargo, igualmente posible contemplar a Aristóteles como una breve y rara excepción en mitad de una tradición de pensamiento -la griega, y especialmente la presocrática - caracterizada más por la celebración de la aporía que por aportar una garantía a la «realidad» propia de las físicas positivas.
} 
los permanecer en constante actividad. Operan así un nuevo reparto donde la vida se distingue tanto de la materia (principio pasivo que carece de todo estatuto real en la clasificación de los seres) como del pensamiento abstracto de los incorpóreos, que constituyen lo radicalmente inactual. Los seres mismos no son ya objeto del pensamiento dialéctico; la Lógica no «muerde» la sustancia corpórea, y por tanto no puede pretender oponerse a ningún «devenir» (y más en concreto, como en el platonismo, al de la materia fluyente e inasible que subyace a todas las cosas) porque es ella la que promueve, en estrecha complicidad con la materia, ese tiempo espurio de la infinita división. Sin embargo, entre tanto ha sido necesario liberar el dominio de los cuerpos de todas las aporías del flujo y el movimiento, y ello no ha podido lograrse más que al precio de operar un ocultamiento (paralelo quizá al de los epicúreos con el clinamen) que sustrae el movimiento natural al pensamiento «por conceptos», origen de las aporías, echando mano de toda una sub-realidad inmanente que alberga, como en un doble fondo menor que cualquier representación posi$b l e^{91}$, la intransferible cualidad individual de los cuerpos a fin de garantizar la armonía entre lo uno y lo múltiple en que consiste la distensión tonal del alma de Zeus. Surge así la novedosa solución estoica a este problema atávico de la filosofía, consistente ahora en la generación de lo múltiple por los sucesivos grados de distensión de un Uno que, sin embargo, sigue presente, como principio activo, en cada uno de los «muchos», garantizando así la posibilidad de un retorno cíclico a la pureza inicial y la consiguiente y renovada multiplicación ${ }^{92}$.

En su afán por considerar real sólo lo que es en acto, el estoicismo se desentiende entonces de un fondo y una altura «virtuales» a los que sólo puede catalogar, cuando comparecen, como enfermedad del cuerpo (no es casualidad, en ningún caso, que la enfermedad, estado de descomposición de la actividad de un cuerpo, consista en la receptividad pasiva de éste a las ilusiones noéticas de división, sucesión, yuxtaposición y contigüidad). Su filosofía resulta así inseparable de una reacción muy hostil frente a Aristóteles, pero al deshacer aquella descomunal empresa no pueden evitar liberar lo que ésta mantenía a buen recaudo, y es ahí donde vuelve a sonar como una maldición el eco de una sabiduría arcaica (la de Zenón, Heráclito o Anaximandro) que denunciaba como contradictoria e imposible la pretendida componenda de lo uno y lo múltiple a la que procede toda «Física» y que el floreciente mundo griego parecía singularmente destinado a promover. Si las

\footnotetext{
${ }^{91}$ Los estoicos apoyan todo su sensualismo en su confianza ciega en una aprehensión intuitiva, subsensorial, de la sustancia e identidad individual del ser por parte del principio rector (alma) que lo pone a cubierto de las aporías del cambio y salva la noción común de «sustancia individual». Cf. Plutarco, Nociones comunes, 1083D-E, y nota 384 de R. Caballero.

92 Son los estoicos, como supo ver un jovencísimo Bergson, quienes inauguran, en el proceso de distensión, la reducción de diferencias «de cualidad» (o naturaleza) a diferencias «de cantidad» (o grado). Cf. Cours d'histoire de la philosophie grecque, Lycée Henri IV, 1894-95, en Bergson, Cours, IV, París, PUF, 1998.
} 
sagaces acometidas de Plutarco 93 , destinadas a mostrar que el platonismo y su «demiúrgica» dualidad materia-pensamiento es la única manera de salvar la estabilidad del mundo, no pueden ser calificadas más que de capciosas, no dejan por ello de retratar acertadamente la operación de ocultamiento a la que proceden los estoicos y que parece la obligada contrapartida de impugnar e invertir la aparatosa trascendencia de las Ideas: tanto la sustancia (ousía) como la cualidad individual (idios poión $)^{94}$ quedan selladas a fuego en los cuerpos al modo de garantes abstractos de todo el edificio de la realidad. Es por ello que el estoicismo puede ser descrito acertadamente como sensualismo idealista o idealismo sensible, porque ésta es la innovadora manera que tiene de superar las aporías que refulgen en el inicio del pensamiento griego y a las que los filósofos retornan cada vez que quieren apuntalar la realidad o erigir una Física estable. Y es en este sentido que los estoicos retoman a Heráclito: él es para ellos, por decirlo con una noción extraída de su propio sistema, la ekpýrosis del pensamiento griego, aquello que hace arder las físicas platónica, aristotélica y atomista, y a partir de cuya pureza aporética pueden proceder a su particular diakósmesis o extinción-traición al maestro, incurriendo con su ontología tonal en su particular «parricidio» 95 .

Pero finalmente, la Física estoica no es autosuficiente, y en ella subsiste, como veíamos, una tensión no resuelta entre lo común y lo parcial (o, en otros términos, entre lo real y lo ilusorio-enfermizo, entre la distensión y la división) que debe encontrar solución o alivio en otra parte del sistema. Que su Ética individualista, introspectiva y a todas luces sobrehumana deba cargar con la responsabilidad de solventar lo que su ontología destapa es a la vez admirable y sintomático. Contemplado desde la Ética que corona el sistema, el estoicismo hace honor a su héroe mitológico predilecto y parece ciertamente movido por una tracción hercúlea que reconduce los problemas crónicos del pensamiento, que rondan a la filosofía como sus fantasmas, a la parcela donde el sabio se siente lo bastante fuerte como para soportar su peso y presentarles batalla en un duelo personal.

\section{Referencias bibliográficas}

ARISTÓteles, Física, Madrid, Gredos, 2008.

ARISTÓTELES, Metafisica, Madrid, Gredos, 2006.

93 Cf. Nociones comunes, 50.

94 Ello sería extensible a los otros dos «primeros géneros» estoicos, el «modo» (pos échon) y la «relación» (prós ti pos échon), a los que Plutarco alude significativamente como «sustratos» (hypokeíme$n a$, término que corresponde específicamente a la materia subyacente). Cf. Plutarco, Nociones comunes, $1083 \mathrm{D}$, y nota 378 de R. Caballero.

95 Sobre la imposibilidad de considerar el fuego de Heráclito como «principio físico» o «elemento» de alguna doctrina de ciencia primitiva, cf. Razón común, Zamora, Lucina, 1985, especialmente fr. 74, y comentario de A. García Calvo. 
Aristóteles, Tratados de lógica (Órganon), Vol. 1, Madrid, Gredos, 2000.

BOERI, M. D., «Incorpóreos, tiempo e individuación en el estoicismo. A propósito de 'Tiempos, objetos y sucesos en la metafísica estoica' de Ricardo Salles», en revista Dianoia, 51, noviembre de 2003.

BRÉHIER, É., La théorie des incorporels dans l'ancien stoïcisme, París, Vrin, 1987 ( $7^{\mathrm{a}}$ ed.).

Caballero, R., «Plutarco y el modelo cosmológico-espacial de Crisipo: ¿el mundo en el centro del vacío?», en A. Casanova (ed.), Plutarco e l'etá ellenistica, Florencia, Università degli studi di Firenze, 2005, págs. 315-336.

Cicerón, Sobre la adivinación / Sobre el destino, Madrid, Gredos, 1999.

CRISIPO DE Solos, Testimonios y fragmentos, Vol. II, Madrid, Gredos, 2006.

Lógica estoica, recopilación y traducción de Adrián Castillo (http://galileo.fcien. edu.uy/Grisipo de Solos - Logica Estoica.pdf).

Diógenes LAercio, Vidas de los filósofos ilustres, Madrid, Alianza, 2008.

Deleuze, G., Lógica del sentido, Barcelona, Paidós, 2005.

García Calvo, A., Contra el tiempo, Zamora, Lucina, 2001.

García Calvo, A., De Dios, Zamora, Lucina, 1996.

García Calvo, A., Razón común. Edición crítica, ordenación, traducción y comentario de los restos del libro de Heraclito, Zamora, Lucina, 1985.

GoldschmidT, V., Écrits I, París, Vrin, 1984.

Le système stoïcien et l'idée de temps, París, Vrin, 1969.

Hadot, P., The inner citadel: the Meditations of Marcus Aurelius, Harvard University Press, 1998.

Marco Aurelio, Meditaciones, Madrid, Cátedra, 2011.

PArdo, J.L., El cuerpo sin órganos. Presentación de Gilles Deleuze, Valecia, Pretextos, 2011.

Plutarco, Obras morales y de costumbres XI, Madrid, Gredos, 2004.

Posidonius, Vol. 1, The fragments, L. Edelstein, I.G. Kidd (eds.), Cambridge University Press, 1989.

Vol. 3, The translation of the fragments, I.G. Kidd, 1999.

SEllars, J., "Aiôn and Chronos: Deleuze and the Stoic Theory of Time», en Collapse, Philosophical Research and Development, Vol. III, 2007.

SeXto Empírico, Contra los profesores, Madrid, Gredos, 1997.

Zambrano, M., El pensamiento vivo de Séneca, Madrid, Cátedra, 1987.

Antonio Dopazo Gallego

Departamento de Filosofía Teorética

Universidad Complutense de Madrid

antoniod@filos.ucm.es 